\title{
SOME EFFECTS OF LEVALLORPHAN \\ ON RESPONSES TO MEPERIDINE
}

\author{
M. J. Schiffrin, Ph D., ${ }^{*}$ R. C. Balagot, M.D., $\nmid$ and Max S. Sadove, M.D.
}

THE PURPOSE OF THIS STUDY was to measure some of the effects of levallorphan on analgesia and respiratory depression produced by meperidine. Of particular interest was the determination of the ratio of meperidine to levallorphan which, when, they are given simultaneously, would provide adequate analgesia without respiratory depression.

\section{Methods and Material}

Patients with chronic pan of sufficient severity to require the use of narcotic analgesics served as the subjects for the experiments. They were not told what drug they were receiving or what was expected of them. All subjects were given saline, meperidine, and two ratios of meperidine and levallorphan in successive trials; thus each patient served as his own control and as a basis for comparison. Effects on respuration were measured by testing the response of minute volume to the inhalation of 5 per cent carbon droxide in oxygen. We believe this to be a more sensitive means of judging the reactivity of the respiratory centre than the measuring of respiratory minute volume while the subjects are breathing room air. Respiration was measured on a 13-litre Collins respirometer just before the injection of the drug, and 15,30,60, and 90 minutes thereafter whenever this was practicable. The amount of analgesia was evaluated and recorded with the aid of a scale in which 0 indicated no pain; 1 , slight pan; 2 , moderate pain, and 3 , severe pain. Each patient was questioned regarding the character and degree of pain before and 15 and 30 minutes after the injection and at 30-minute intervals thereafter for a total of 4 hours. Accordingly, differences between the pre-injection pain level and the respective levels following the injection of the drug gave numbers which were used to indicate the amount of pain relief or "analgesia" for each time interval. Thus a difference of 0 meant no pain relief; 1 , slight relief; 2 , moderate relief, etc. These numbers were added for the entre period of the experiment to yleld a numerical expression of total pain relief. Observations of side reactions were also recorded. The patients were supine throughout the time of observation. A period of at least 24 hours separated each experiment. All patienis were in pain (Grade 2 or 3 ) at the beginning of each trial. They were not permitted to receive a narcotic within 6 hours prior to any observation period.

The solution of meperidine (Demerol) hydrochloride contained $50 \mathrm{mg} / \mathrm{ml}$. and that of levallorphan (Lorfan) ${ }^{1}$ tartrate $1 \mathrm{mg} . / \mathrm{ml}$. Half of the patients received injections by the intramuscular route, and the other half by the subcutaneous route. The standard dose of meperidine was $100 \mathrm{mg}$. for four of the

-From the Department of Climcal Research, Hoffmann-La Roche Inc.

†Division of Anesthesılogy, Unıversity of Illınois College of Medicıne, Chicago, Illınoss.

1 Supplied by Hoffmann La Roche Inc. 
patients and $50 \mathrm{mg}$. for the other two. The latter were in such poor physical condition that doses higher than $50 \mathrm{mg}$. meperidine were eontraindicated. When levallorphan was administered with. meperidine, the two drugs were mixed in the same syringe immediately before injection. The ratios by weight of meperidine hydrochloride to levallorphan tartrate that were studied were 100:1, 100:1.5 and 50:1. All subjects were given meperidine alone and the 100:1.5 mixtures; in addition, three received the 50:1 combination and another three the 100:1 mixture.

\section{ResULts}

The effects of meperidine alone and of the meperidine-levallorphan mixtures on the response of respiratory minute volume to carbon dioxide are shown in Table I. All of the data are expressed as percentages of the normal response to the $\mathrm{CO}_{2}$ challenge in each particular patient. The effect of $\mathrm{CO}_{2}$ was consistently an increase in the tidal volume with very little change in the respiratory rate. The product of rate times tidal volume (minute volume) was used as the basis for the data in Table I. Accordingly, figures below 100 per cent indicate depres-

TABLE I

Respiratory Minute Volume after Carbon Dioxide Challenge Expressed as Pek Cent of Control Response to Carbon Dioxide

\begin{tabular}{|c|c|c|c|c|c|c|c|}
\hline & \multicolumn{3}{|c|}{ Meperidine } & \multicolumn{4}{|c|}{ Minute volume ( $\%$ of control) } \\
\hline & Patient & (mg.) & Route & 15 & 30 & 60 & 90 \\
\hline (a) Meperidine alone & $\begin{array}{l}\text { George B. } \\
\text { Jean M. } \\
\text { John J. } \\
\text { Claude W. } \\
\text { Sophie I., } \\
\text { George A. }\end{array}$ & $\begin{array}{r}100 \\
100 \\
100 \\
100 \\
50 \\
50\end{array}$ & $\begin{array}{l}\text { I.M. } \\
\text { I.M. } \\
\text { I.M. } \\
\text { S.C. } \\
\text { S.C. } \\
\text { S.C. }\end{array}$ & $\begin{array}{l}- \\
\overline{-} \\
84.8 \\
95.0 \\
80.6\end{array}$ & $\begin{array}{c}82.3 \\
64.6 \\
77.7 \\
105 \\
103 \\
88.2\end{array}$ & $\begin{array}{c}110 \\
71.7 \\
75.7 \\
96.1 \\
111\end{array}$ & $\begin{array}{c}1 \overline{104} \\
109 \\
9 \overline{7} .2 \\
130 \\
89.3\end{array}$ \\
\hline (b) $100: 1$ & $\begin{array}{l}\text { Claude II. } \\
\text { Sophie D. } \\
\text { George A. }\end{array}$ & $\begin{array}{r}100 \\
50 \\
50\end{array}$ & $\begin{array}{l}\text { S.C. } \\
\text { S.C. } \\
\text { S.C. }\end{array}$ & $\begin{array}{l}113 \\
82.0 \\
115\end{array}$ & $\begin{array}{l}131 \\
101 \\
104\end{array}$ & $\frac{117}{102}$ & $\underline{113}$ \\
\hline (c) $100: 1.5$ & $\begin{array}{l}\text { George B. } \\
\text { Jean NI. } \\
\text { John J. } \\
\text { Claude W. } \\
\text { Sophie D. } \\
\text { George A. }\end{array}$ & $\begin{array}{r}100 \\
100 \\
100 \\
100 \\
50 \\
50\end{array}$ & $\begin{array}{l}\text { I.M. } \\
\text { I.M. } \\
\text { I.M. } \\
\text { S.C. } \\
\text { S.C. } \\
\text { S.C. }\end{array}$ & $\begin{array}{l}\overline{-} \\
11 \overline{7} \\
104 \\
115\end{array}$ & $\begin{array}{c}105 \\
103 \\
96.0 \\
102 \\
121 \\
99.7\end{array}$ & $\begin{array}{l}115 \\
116 \\
117 \\
128 \\
122 \\
\end{array}$ & $\begin{array}{l}\overline{126} \\
1+3 \\
103 \\
106\end{array}$ \\
\hline (d) $50: 1$ & $\begin{array}{l}\text { George B. } \\
\text { Jean M. } \\
\text { John J. }\end{array}$ & $\begin{array}{l}100 \\
100 \\
100\end{array}$ & $\begin{array}{l}\text { I.M. } \\
\text { I.M. } \\
\text { I.M. }\end{array}$ & $\frac{-}{-}$ & $\begin{array}{l}114 \\
151 \\
109\end{array}$ & $\begin{array}{l}132 \\
129 \\
98.6\end{array}$ & $\underline{128}$ \\
\hline
\end{tabular}

sion of the respiratory reaction to 5 per cent carbon dioxide in oxygen. Following the administration of meperidine alone, only two of the nine readings were 100 per cent or more of control values during the first 30 minutes. Two of the five determinations at 60 minutes were still depressed significantly, and one of the five values at 90 minutes was 89.3 per cent. It is, therefore, concluded that respiratory depression after meperidine, as it is used clinically, can be demon- 
strated as early as 15 minutes after injection and that this depression may persist for as long as 90 minutes after the drug was administered. It is self-evident from the data presented that the 50:1 mixture prevented respiratory depression. The 100:1.5 mixture was also effective in preventing respiratory depression since of 18 determinations only two were below 100 per cent, and these were of questionable clinical significance ( 96 per cent and 99.7 per cent respectively). Of the recordings for the 100:1 mixture, all except one are above control values: The 82 per cent reported for patient Sophie D. at 15 minutes is the lowest figure obtained for any mixture of meperidine-levallorphan in this study. This patient was in very poor condition on the day of this particular experiment. She had so much upper abdominal pain that her tidal volume was less than $200 \mathrm{ml}$. The other two patients did at least as well with the 100:1 mixture for the first 30 minutes as they did with the 100:1.5 ratio. We, therefore, conclude that a ratio of 100:1 provides protection against respiratory depression.

The values at 30 minutes for meperidine alone and the 100:1.5 mixture were submitted to an analysis of variance which is summarized in Table II. The results indicate that while there is no significance to the variance between subject responses, there is statistical significance $(P<0.05)$ to the variance between treatment effects.

The average pain rehef for all treatments is summarized in Table III. These figures represent the average of all the observations for each period. All the drugs provided significantly greater analgesia than did saline. There was no appreciable difference in the analgesia produced by meperidine alone and the

TABLE II

Summary of Analysis of Variance

\begin{tabular}{lcrr}
\hline Source & $\begin{array}{c}\text { Degrees of } \\
\text { freedom }\end{array}$ & $\begin{array}{c}\text { Mean } \\
\text { square }\end{array}$ & "F" ratio \\
\hline Subjects & 5 & 221478 & 2453 \\
Treatment & 1 & 943570 & $10451^{*}$ \\
Error & 5 & 90284 & \\
\hline$* P<005$ & & &
\end{tabular}

TABLE III

Average Pain Relief

\begin{tabular}{|c|c|c|c|c|c|c|c|c|c|c|}
\hline \multirow{2}{*}{\multicolumn{2}{|c|}{ Treatment }} & \multicolumn{9}{|c|}{$\begin{array}{c}\text { Average pann relief* } \\
\text { (minutes) }\end{array}$} \\
\hline & & 15 & 30 & 60 & 90 & 120 & 150 & 180 & 210 & 240 \\
\hline Meperıdıne & & $\begin{array}{ll}0 & 0 \\
1 & 2\end{array}$ & $\begin{array}{ll}0 & 5 \\
1 & 5\end{array}$ & $\begin{array}{rll}-0 & 0 \\
1 & 4\end{array}$ & 07 & 07 & 05 & 03 & 03 & 03 \\
\hline $\begin{array}{l}\text { Meperidine plus } \\
\text { levallorphan } 50\end{array}$ & 1 & 03 & 13 & 20 & 07 & 07 & 03 & 03 & 03 & 03 \\
\hline $\begin{array}{l}\text { Meperidine plus } \\
\text { levallorphan } 100 \\
\text { Meperidine plus }\end{array}$ & 15 & 13 & 10 & 12 & 07 & 07 & 05 & 05 & 03 & 03 \\
\hline $\begin{array}{l}\text { Meperidine plus } \\
\text { levallorphan } 100\end{array}$ & 1 & 13 & 17 & 10 & 07 & 07 & 07 & 07 & 07 & 07 \\
\hline
\end{tabular}

${ }^{*} 0$, no pain relief, 1 , slight, 2 , moderate A negative number indicated that the pain was greater than it was at the start of the observation period 
combinations with levallorphan. We were somewhat surprised at the short duration of meperidine analgesia in three patients who failed to have further relief of pain 90 minutes after the injection. In one subject (George A.), however, analgesia persisted for four hours after meperidine alone and in combination with levallorphan.

Reactions to meperidine and the meperidine-levallorphan mixtures were recorded because it was of interest to know not only which ratio would provide analgesia without respiratory depression, but also which would produce the fewest number of untoward reactions. Table IV provides a summary of these

TABLE IV

Number of Side Reactions

\begin{tabular}{|c|c|c|c|c|c|c|c|}
\hline \multirow[b]{2}{*}{ Reactions } & \multirow[b]{2}{*}{ Meperidıne } & \multicolumn{6}{|c|}{ Meperidine levallorphan } \\
\hline & & $\$ 00$ & 1 & 100 & 15 & 50 & 1 \\
\hline Sedation & 2 & \multirow{5}{*}{\multicolumn{2}{|c|}{1}} & & 1 & 2 & \\
\hline Dryness of the mouth & 1 & & & & 2 & & \\
\hline Excessive perspiration & 2 & & & & 2 & 3 & \\
\hline Mental confusion & 1 & & & & 1 & 1 & \\
\hline $\begin{array}{l}\text { Headache } \\
\text { Tired }\end{array}$ & & & & & & & \\
\hline $\begin{array}{l}\text { Tired } \\
\text { Nausea }\end{array}$ & 1 & \multirow{2}{*}{\multicolumn{2}{|c|}{1}} & & & & \\
\hline $\begin{array}{l}\text { Nausea } \\
\text { Vertigo }\end{array}$ & 1 & & & & 1 & & \\
\hline Total number of patients & 6 & & & & 6 & 3 & \\
\hline Reactions per patient & 13 & & 66 & & 12 & & 3 \\
\hline
\end{tabular}

observations. The number of reactions per patient was highest with the 50:1 ratio. There was no significant difference between meperidine alone and the 100:1.5 mixture. The ratio of 100:1 gave the lowest frequency of undesirable reactions. The very low incidence of nausea and the absence of emesis in this series are probably due to the fact that all the patients were in pain at the time the drugs were given and they were recumbent throughout the experiment. The effects of tolerance would also serve to reduce the number of reactions.

\section{Discussion}

Hamilton and Cullen ( 1$)$, in an excellent clinical report on levallorphan, deliberately induced respiratory depression by the intravenous injection of narcotics in anaesthetized patients. They then gave levallorphan intravenously to overcome the depression. In thirty such cases, they used meperidine in doses of 25 to $450 \mathrm{mg}$. Our analysis of their data indicates that they used ratios of 25:1 to $300: 1$ with an over-all average ratio of $96: 1$. It would thus appear from their study and our own that a ratio of 100:1 is sufficient to prevent depression if both drugs are given simultaneously, and to restore respiration when levallorphan is given after the appearance of meperidine-induced depression.

This study demonstrates the value of studying drug effects on respiration by using the carbon dioxide technique. The burden that a drug places on the respiratory mechanism may not always be apparent if observations are limited to 
rate, tidal volume, alveolar $\mathrm{CO}_{2}$ and oxygen. The respiratory system will compensate as best it can in order to maintain homeostasis and, therefore, tests for the adequacy of respiratory exchange reveal only the over-all results. Such tests do not indicate the load or burden upon the respiratory centre. For example, none of our subjects showed any respiratory embarrassment while breathing room air. However, the test with 5 per cent carbon dioxide revealed the depression of the respiratory centre, and uncovered the inability of the system to compensate for this additional stress. Clinically, this may imply a diminution in the patient's "reserve," and his lack of capacity to compensate as it relates to respiratory exchange. The clinical significance in anaesthesiology includes the necessity of allowing for this hidden depression whenever narcotic analgesics are used. For example, although the patient who is brought to sug gery an hour after being given a narcotic may appear to have good respiratory function, the system is, in fact, already working under a handicap and may be very brittle in its response to inhalation anaesthesia. These same considerations apply in obstetrics when the mother is given a narcotic analgesic within an' hour of delivery. Her respirations may be normal, but the child may have difficulty in overcoming the added burden of a depressed respiratory centre. These factors argue in favour of the use of a combination of narcotic analgesic and antagonist even when respiration appears normal, as a means of increasing the safety factor The clinical usefulness of such combinations has been demonstrated by a number of investigators (2-6).

Although the data from the number of patents in this study may not lend themselves well to complete statistical analysis (with its mathematical expressions of probability and significance), it cannot easily be denied that there are clinical implications to be derived from very careful observations on a small selected group.

\section{SUMMARY}

Meperidine hydrochloride in doses of 50 and $100 \mathrm{mg}$ depresses the respiratory response to 5 per cent carbon dioxide in oxygen. This depression may be observed as early as 15 minutes and as late as 90 minutes after subcutaneous or intramuscular injection.

A mixture of meperidine hydrochloride and levallorphan tartrate in a ratio of 100:1 prevents this depression, does not interfere with analgesia, and does not produce more undesirable reactions than does meperidine itself.

\section{RÉSUMÉ}

Le but de cette étude est d'évaluer quelques-uns des effets du levallorphan sur l'analgésie et la dépression respiratoire produites par la mépéridine.

Pour réaliser cette expérience nous avons choisi comme sujets des malades dont les douleurs chroniques nécessitaient l'usage de narcotiques. On a donné à tous les sujets du sérum physiologique, de la mépéridine et deux doses de 
mépéridine et levallorphan dans des épreuves successives: ainsi, chacun des malades devenait son propre contrôle sur une base de comparaison.

On a mesuré les effets sur la respiration en comparant les effets sur le volume minuté de l'inhalation de 5 pour cent de gaz carbonique et c'oxygèène. L'analgésie a été appréciée et enregistrée à l'aide d'une échelle où 0 indique aucune douleur; 1 , une douleur légère; 2 , une douleur modérée; 3 , une douleur intense.

Le chlorhydrate de mépéridine à la dose de 50 à $100 \mathrm{mgm}$. déprime la réponse de la respiration à un mélange de gaz carbonique de 5 pour cent et d'oxygène. On peut observer cette dépression aussi bien 15 minutes après l'injection souscutanée ou intramusculaire que 90 minutes après cette injection.

Un mélange de chlorhydrate de mépéridine et de tartrate de levallorphan dans une proportion de 100 pour 1 fait disparaître cette dépression, ne modifie pas l’analgésie et ne donne pas plus de réactıons indésirables que ne le fait la mépéridine seule.

\section{REFERENCES}

1 Hamilton, W K , \& Cullen, S G Supplementation of Nittrous Oxide Anesthesia with Opiates and a New Opiate Antagonist Anesthesiology 16. 22-28 (Jan., 1955).

2. Foldes, F. F., Ltpschitz, E, Weber, G. M., Swerdlow, M \& Ptrk, L. A. Levallorphan (Lorfan) and Alphaprodine (Nisentl) in Anesthesia. J.A M A. 160. 168-175 (Jan., 1956).

3. GaAmD, R. C Preoperative Use of a Combination of Levo-Dromoran Tartrate and a New Narcotic Antagonist. Minnesota Med 38. 637-639 (Sept., 1955).

4 Kepes, E. R., \& Margolius, B. R The Effect of Nisentil HCl with Lorfan Tartrate on Respiration during Vitrous Oxide Anesthesia. Proc World Cong Anesthesiologists, Scheveningen (Hague) Holland, pp 201-204 (Sept, 1955).

5 Stoelting, V K, \& Hicks, M L Combined Use of Narcotic and Narcotic Antagonist in the Supplementation of Anaesthesia. Canad Anaesth Soc. J 3. 107-112 (April, 1956).

6. Cullen, S C, \& Santos, C. C Analgesia for Postoperative Pain without Respiratory Depression Anesthesiology, 16. 674-677 (Sept., 1955). 